\title{
Principal Management in Strengthening Character Education
}

\author{
Novi Yulianti*, Yusrizal, Nasir Usman \\ Educational Administration Postgraduate \\ Universitas Syiah Kuala \\ Banda Aceh, Indonesia \\ *noviyulianti.aceh22@gmail.com
}

\begin{abstract}
The principal who acts as a leader in forming and managing character education strengthening should be carried out to the maximum, which is full of responsibility and sustainable. The purpose of this research is to determine the planning, implementation, monitoring, and evaluation in the application of strengthening character education. This research uses qualitative methods with descriptive analysis. The data collection techniques used were: interviews, observation, and documentation studies. The research subjects were principals, teachers and students. The results of the study indicate that: 1) planning for strengthening character education is planned in school meetings, there are special programs related to religious events, group schedules for clean Fridays, homeroom notes sheets, there are rewards and punishments for carrying out and not carrying out, 2) the implementation by providing motivation to students, support, commitment and cooperation with all school apparatus so that it can be carried out properly, 3). Supervision is carried out jointly such as the presence of deputy principals who help, teachers, homeroom teachers and this supervision is carried out every day, and 4) the results of the evaluation carried out are obtained by the awareness of students in carrying out character education strengthening in schools, and also obtained there are still students who violate and have not fully implemented the application of character education. commitment and cooperation with all school officials so that it can be carried out properly, 3). Supervision is carried out jointly such as the presence of deputy principals who help, teachers, homeroom teachers and this supervision is carried out every day, and 4) the results of the evaluation carried out are obtained by the awareness of students in carrying out character education strengthening in schools, and also obtained there are still students who violate and have not fully implemented the application of character education. commitment and cooperation with all school officials so that it can be carried out properly, 3). Supervision is carried out jointly such as the presence of deputy principals who help, teachers, homeroom teachers and this supervision is carried out every day, and 4) the results of the evaluation carried out show that there is awareness of students in carrying out character education strengthening in schools, and also obtained there are still students who violate and have not fully implemented the application of character education.
\end{abstract}

Keywords-principal management, strengthening character education

\section{INTRODUCTION}

Recently, character education has been in the spotlight in various countries because of the many phenomena or events that are increasingly happening, for example cases of corruption, crime by teenagers, drugs, free sex and so on. Indonesia is one of the countries that is intensively instilling and improving moral education among children and adolescents. Not only in Indonesia, it turns out that this step has also been taken by other countries, for example, Singapore, America, Britain, Japan, and several other countries.

Character education at this time needs to be implemented to overcome the moral crisis that is hitting this country. For example, the physical weakness of children due to lack of exercise, low sense of art and aesthetics as well as ethical understanding that has not been formed during the education period. Character education which is an education that places great emphasis on value aspects, it is hoped that humans will be born who have high sensitivity to upholding the values of truth, justice, humanity, and progress which are the breath (spirit) in human life on this earth. Someone who grows up with good character will become a candidate for the next generation who can change the nation towards a better civilization.

The rapid development of information technology causes a decline in the character of Indonesian children because positive and negative information is easily accessible both through conventional and digital media [1]. Because filtering information from digital media is more complicated than conventional media, we need to provide children with knowledge, and manners before allowing them to access that information for learning media resources. Children and youth who will ensure the sustainability of society must have good character, not only knowledge [2]. Qualified and trained individuals equipped with positive values are needed to create a peaceful and successful society.

Since the beginning of this century, scholars in the US, UK, Canada, Australia, and Japan have found that the world's new crisis is "moral degeneration" and ignorance of character education; Many factors contribute to moral degeneration [3]. The loss of social values tops the list and is followed by 
dysfunctional family education, ignorance of character education in schools, and bad examples set by the media. Many experts say that character education must start from early childhood [4]. At an early age of 0-6 years, the brain develops very rapidly up to 80 percent. That is the time when the child's physical, mental and spiritual will begin to form.

The problem of the character of students is an important part that must be strengthened through learning. This is supported by Sardjijoa and Hapzi's research results [5] which integrates characters in Science learning through process skills activities which can strengthen the scientific attitude. In the field learning in Indonesia was originally education character is charged to two subjects, namely: religion and nationality. But on In fact, the process of planting and shaping the character of students has not been sufficiently integrated through specific learning but need to be integrated into all learning. There are several things that make education character is not optimal if only integrated through two lessons, namely: (1) both subjects it tends to only provide knowledge about values through material/substance; (2) activities learning in both subjects is generally inadequate, encouraging the internalization of values to each student so that they behave tough; and (3) the two subjects are not maintained in the process of inculcating the character of students because in the process of planting character requires habituation which will become the culture and morals of students.

The choice of subjects that are integrated with character is in line with the challenges of the 21st century with the rapid development of technology that is applied in various areas of life in society [6]. Therefore, learning is needed that can prepare students who have science and technology literacy and are able to think comprehensively in solving real-life problems.

The process of inculcating character education in Indonesia has been carried out since an early age, for example in the realm of PAUD or Kindergarten (TK) education, where teachers have various varied ways to instill these moral values, for example through storytelling, games (games), songs, and so on. In the realm of basic education and secondary education, there are several subjects that instill moral education or character education in them. This is also found in the realm of higher education, where there are courses on Citizenship, Pancasila or Religious Education. The nation's character is a mental attitude which is scientifically referred to as a system of cultural values and attitudes [7].

Education in Singapore is very adapted to the development of children [8]. This means that in the masses, the stage of student development, he always experiences the process of making candy from stage to stage, so that each student's personal psychology will not always be the same. So that students from 3-7 years old should not be faced with hard lessons, for example mathematics. Because this will affect their mindset, which should still be at play age, they are faced with a very heavy educational process so that at the stage they enter the middle and upper education process they get bored quickly and don't want to linger in the classroom. In Singapore, for example, students provide a learning method of writing while listening to music when they enter elementary school grade 1 and it is adjusted to their age development. This is different from Indonesia where students are teachers and mathematics (without music) when they are still in kindergarten. So that students who are still primary age are forced to understand mathematics and learn to read. Culture in Japan plays a very big role in the process of instilling morals or character in a child. Families, especially mothers, have a very big role in educating a child. There is the term Kyoiku Mama which means that a mother never stops encouraging her children to learn and creates a balance in education, both physically, emotionally, and socially.

The Character Education Partnership identifies three important aspects of character [9]: understanding, commitment, action. While these are intended to be applied to student development outcomes from character education, they can also be applied to staff development. An effective principal needs to (1) "get it", (2) "buy it", and (3) "run it". In other words, leading a character school requires that the principal first fully understand what is meant by quality character education (most do not). Then the principal must be totally committed to this vision and really want to make it happen under his supervision. last,

Building students' character into a culture requires several stages in creating characteristic situations first [10]. This creation is strongly influenced by the situation and conditions in which the learning model is applied and the implementation of values. Character is considered as the embodiment of a person's positive personality development, both intellectually, socially, emotionally, and ethically [11]. Good character is the most coveted goal. The application of character education must refer to the school's vision and mission [12]. In general, the school's vision and mission is to produce students who excel and have noble character. The achievement of the school's vision and mission will bring students to the school's educational goals. In an effort to build the character of students, of course, must be supported by a good environment [13]. The environment usually emphasizes the desired moral values.

The school is a very strategic educational organization, even the main one after the family, to shape the character of students. Every school should make the quality of character as one of the Quality Assurance that must be owned by every school graduate. The success of educational organizations in the application of character education cannot be separated from the leadership management of the principal in organizing all the potential of existing schools. Organizational goals can be achieved effectively and efficiently is largely determined by the expertise of a leader. The principal in managing the implementation of character education has responsibility for all aspects of education ranging from responsibility for the learning process in the classroom to organizing the educational unit environment. 
In other words, the formation and environment that includes the physical environment and school culture, school management, curriculum, educators, and teaching methods. Character building through environmental factors can be done through several strategies, including exemplary, intervention, habituation that is carried out consistently and strengthening. Development in character building requires exemplary that is transmitted, intervention through the learning process, training, continuous habituation in the long term that is carried out continuously and strengthening, and must be balanced with noble values, a must-have for every school graduate by continuing the values that are prioritized from the five values of character education and can be started from values that are essential, simple and easy to implement in accordance with the conditions of each school, namely Religious, Nationalist, Integrity, Independent, Mutual Cooperation.

Character education is defined as education that develops the character values of students so that they have values and character as their own character, apply these values in their lives, as members of society and religious citizens, nationalist, productive and creative [14].

In character education in schools all components must be involved including the components of education itself, namely curriculum content, learning and assessment processes, handling or managing subjects, school management, implementation of co-curricular activities or activities, empowerment of infrastructure, financing, and work ethic of all school/environmental residents [15].

Character education has a very important role in human life position as an individual being and at the same time a creature social. Education is an effort to treat humans to achieving goals. A goal is something to hope for achieved after an attempt is completed. As something to be achieved, the goal expects it changes in behavior, attitude and personality that have been good as expected after students experience education.

Noble morality has always been the main target of the educational process, because morality is considered the basis for the balance of human life which is the determinant of success for other pedagogical potentials. Morals hint at human moral problems, about knowledge of good values, which a person should have and are reflected in every behavior and action. This behavior is the result of self-awareness. Someone who has good values in his soul and can apply them in everyday life is called a person who has character or character.

In an effort to answer various problems that arise, challenges, demands and orientation of education and learning, it is necessary to rearrange or transform education based on character. This is intended to provide a meaningful life for students, educators, and stakeholders related to education. For this reason, strengthening character education is launched as a program to improve the competence of students and $21 \mathrm{st}$ century education personnel in responding to various needs.
Character education in schools is also closely related to school management or management. Management in question is how character education is planned (planning), implemented (actuating), and controlled (evaluation) in educational activities in schools adequately. Such management includes values that need to be instilled, curriculum content, learning, assessment of educators and education personnel or other related components. Thus school management is one of the effective media in the application of character education in schools.

Elementary schools have several obstacles, not all teachers have the same abilities, especially integrating character values in the learning process. In this case, the challenge that must be faced by the principal is to be active and also want to be a leader according to the mandate of the law. The principal who is responsible for determining the success or failure of the implementation in the school and his duties as the organizer of the education. Meanwhile, the teacher is in charge of assisting the principal. This study aims to provide an overview of Principal Management in Strengthening Character Education.

\section{METHODS}

In accordance with the background of the problems studied in this study, the place of research used as a data source is the Langsat Gugus State Elementary School, Banda Aceh City. This research is a qualitative research with descriptive analysis. This study seeks to describe or describe what is being studied regarding the management of school principals in strengthening character education in Banda Aceh City State Elementary Schools. Researchers conducted research directly to the location to obtain and collect data. so as to produce descriptive data in the form of written or spoken words and observed behavior

Sources of data in this study, namely: a) Primary data; derived from the field obtained through structured and systematic interviews with competent and knowledgeable informants, in this case principals, teachers, and students at the Langsat Cluster State Elementary School, Banda Aceh City. b) Secondary data; is additional data that comes from written sources and various other sources related to elementary schools.

The subjects to be studied in this research are the principal, teachers and students. Data collection method is one of the most strategic steps in research, because the main purpose of research is to obtain data. The data collection methods used in this study were observation, interviews, and documentation.

Data obtained from observations, documentation, and interviews will have meaning after being analyzed and interpreted by methods of analysis and interpretation of data that are relevant to research needs. The data analysis technique used in this study follows the theory of Miles and Huberman [16] that a data processing process can be carried out through three stages, namely data reduction, data presentation, and drawing a conclusion. The process of data analysis is carried out by researchers continuously. This is done by researchers by 
triangulating data including observation data, interviews, and documentation that are interrelated with one another.

Checking or checking the validity of the data (triangulation). In qualitative research, researchers must be able to reveal objective truth, therefore the validity of data in qualitative research is very important. It aims to measure the level of trust in qualitative research so that it can be justified scientifically. Sugiyono [17] said that triangulation is a data collection technique that combines various data collection techniques and existing data sources. Testing the validity of data in qualitative research using triangulation will further increase the strength of the data when compared to one approach.

\section{RESULTS AND DISCUSSION}

The results of the research on strengthening character education management in elementary schools were obtained using data collection instruments with interviews, observations, and documentation studies, as follows:

\section{A. Principal Planning in Implementing Strengthening Character Education in Elementary Schools}

The planning process made by the principal in implementing strengthening character education is certainly related to the application of character values. So that with good planning it is hoped that it can be carried out properly and become the hallmark of the school in increasing the insight into character education for every student in the school.

Principal management planning in the application of strengthening character education already exists and begins with the preparation of programs at the beginning of the new school year and is contained in document I. The implementation of strengthening character education is prioritized including moral development, congregational prayer, application of discipline, clean Friday, Friday yasin, PHBI, handshake culture, praying before and after studying.

The planning of this character education strengthening program is contained in document I which is the first step taken by the school for the next which can be used in the teaching and learning process, from the start of student attendance to school, until students return home. Document I is planned by holding a coordination meeting in advance with other school officials, to express various ideas, ideas, opinions that cannot be separated from the school's vision and mission as well as the wishes or aspirations of the principal/leader who wants to implement strengthening character education. .

\section{B. Implementation of School Principals in Implementing} Strengthening Character Education in the Langsat Cluster State Elementary School Banda Aceh City

State Elementary Schools have implemented most of the implementation of strengthening character education. What has been planned at the beginning of the new school year is based on the results of a meeting with the elements in the school. The entire plan that has been made will last during the school year, and it will be re-evaluated at the end of the year. The implementation of this cannot be separated from the coordination meeting every month, both at the beginning of the month and at the end of the month in this case to examine obstacles and find solutions if there are obstacles during implementation. Apart from that, the condition of teachers who are ready to work, adequate facilities and infrastructure, to support from parents.

The implementation of strengthening character education has been carried out at the Langsat Cluster State Elementary School, Banda Aceh, with various good collaborations between school officials. The strengthening of character education has been carried out even though there are still things that have not been fully realized, such as discipline with some being late, cleanliness, there is still some garbage in the scattered school environment, praying in congregation there are still students who do not carry out, this is certainly a solution that is not realized fully in order to realize the strengthening of good and efficient character education.

\section{Supervision of School Principals in Strengthening Character Education at the Langsat Cluster State Elementary School, Banda Aceh City}

In implementing the implementation of character education, continuous supervision is needed by the principal. This is to observe the program activities that have been implemented and have not been implemented. The principal carries out direct supervision in monitoring the process of implementing the application of character values, together with the deputy head, Islamic religious education teachers and school residents to coordinate to directly ask problems that occur in the school environment.

The implementation of character education is expected to have a high commitment for every school apparatus in carrying out supervision so that if there are changes in students, the program that has been planned from the start will be carried out well For students who have changes in attitudes, behavior and actions will be rewarded for these changes. Therefore, the role of homeroom teachers, teachers, pickets and other school officials is important for changes for the better.

\section{Evaluation of the Principal in Strengthening Character Education in the Langsat Cluster State Elementary School, Banda Aceh City}

Every activity that has been carried out in an educational institution, of course, an evaluation is carried out regarding the habits that have been carried out in schools related to the application of strengthening character education. The evaluation is an assessment of the aspects carried out, with the aim that the good ones can be maintained and those that have not been implemented will seek solutions or problem solving.

Evaluations in schools are certainly led by a principal and other school officials can help carry out these evaluations. Regarding the Neprializa Evaluation in the journal School 
Culture Management Explains: The objectives of evaluating the school culture and environment are: 1) knowing the achievement targets that have been set; 2) knowing the targets that have been achieved and have not been achieved; 3) knowing the inhibiting factors for achieving the target; 4) knowing the efforts that have been made in order to overcome the obstacles; 5) identify elements of program planning and implementation that need to be improved and developed in order to obtain optimal results.

Evaluation should be done every day to be able to see firsthand what students have not implemented and what is needed. The evaluation carried out at SD Negeri Gugus Langsat is carried out by holding a coordination meeting with the teacher council to find out what is good, and will revise what is not good, thoroughly give rewards to those who are committed to carrying out, and also provide punishment for those who do not comply with the rules.

\section{CONCLUSION}

Principal planning in the implementation of strengthening character education is related to integrated moral development in the Learning Implementation Plan (RPP) relating to the values of religious, nationalist, independent, mutual cooperation and integrity character. And habituation for students which includes congregational prayer, discipline, cleanliness, honesty, handshake culture, praying before and after learning. The implementation of the implementation of character education has been carried out at the Langsat Cluster Elementary School in Banda Aceh with various good collaborations between school officials, in assisting the program from the principal to make students accustomed to character in school. teacher in the field of study that is carried out every day, so that whatever is obtained from the supervision will be used as input and changes when the supervision is evaluated. Evaluation by holding a coordination meeting with the teacher council to find out what is good and who will revise what is not good, thoroughly give rewards to those who are committed to carrying out, and also provide punishment for those who do not comply with the rules..

\section{REFERENCES}

[1] E. Hinta, D. Djou, A. Ntelu, and M. Mirnawati, "Character Education Comparison Of Primary School Students In Indonesia And Japan," PalArch's Journal of Archaeology of Egypt/Egyptology, vol. 17, p. 482493, 2020.
[2] M. Ülger, S. Yiğittir, and O. Ercan, "Secondary school teachers' beliefs on character education competency," Procedia-Social and Behavioral Sciences, vol. 131, pp. 442-449, 2014.

[3] C.S. Cheng, and L. Ro-Yu, Character education and character-trai development enrichment for college students. In Chinese Association of Gifted Education, Paper Presented at the 2007 seminar of Kao Yuan University for General Education May (Vol. 25, p. 2007), 2007.

[4] A. Sobarna, and A. Hakim, "Management character education in kindergarten," Indonesian Journal of Early Childhood Education Studies, vol. 6, pp. 65-73, 2017.

[5] S. Sardjijoa and H. Hapzi, "Mengintegrasikan Karakter Build- masuk ke Kursus Matematika dan Sains di Sekolah dasar," Jurnal Internasional Pendidikan Lingkungan \& Sains, vol. 12, pp. 1547-1552, 2017.

[6] B. Isdaryanti, M. Rahman, Y.L. Sukestiyarno, T.S. Florentinus, and W. Widodo, "Teachers' performance in science learning management integrated with character education," Jurnal Pendidikan IPA Indonesia, vol. 7, pp. 9-15, 2018.

[7] A. Imron and F. Nugrahani, "Strengthening pluralism in literature learning for character education of school students," Humanities \& Social Sciences Reviews, vol. 7, pp. 207-213, 2019.

[8] A. Syamsurrijal, "Observing Character Education in Various Countries Multi Study in Indonesia," Singapore and Japan, vol. 8, 2018.

[9] M.W. Berkowitz, and M.C. Bier, "Based character education," The Annals of the American Academy of Political and Social Science, vol. 591, pp. 72-85, 2004.

[10] N.A. Hidayati, H.J. Waluyo, and R. Winarni, "Exploring the Implementation of Local Wisdom-Based Character Education among Indonesian Higher Education Students," International Journal of Instruction, vol. 13, pp. 179-198, 2020

[11] M. Marzuki, "Pembinaan Akhlak Mulia Dalam Berhubungan Antar Sesama Manusia Dalam Perspektif Islam," Humanika, Kajian Ilmiah Mata Kuliah Umum, vol. 9, 2009.

[12] N. Listiawati, "The implementation of the strengthening character education in sdn 09 mataram city, nusa tenggara barat," Jurnal Pendidikan Karakter, vol. 8, 2018

[13] D.E. Hulawa, "Al-Zarnuji's Character Concept in Strengthening Character Education in Indonesia," Jurnal Pendidikan Islam UIN Sunan Gunung Djati, vol. 4, pp. 25-40, 2018.

[14] M.A. Zubaedi, Desain Pendidikan Karakter. Prenada Media, 2015.

[15] S. Sukiyat, Strategi Implementasi Pendidikan Karakter. Cv Jakad Media Publishing, 2020.

[16] M. Huberman and M.B. Miles, The qualitative researcher's companion. Sage, 2002.

[17] S. Sugiyono, Metode Penelitian Kuantitatif, Kualitatif dan R \& D Bandung: ALFABETA, 2009 